\title{
BLOOD IODINE IN PATIENTS WITH THYROID DISEASE ${ }^{1}$
}

\author{
By D. S. RIGGS,2 E. F. GILDEA, E. B. MAN, ANd J. P. PETERS \\ (From the Departments of Psychiatry and of Internal Medicine, Yale University, School of \\ Medicine, New Haven, and the Medical Service of the New Haven Hospital, New Haven)
}

(Received for publication February 21, 1941)

A reinvestigation of blood iodine in patients with thyroid disorders has been undertaken because it has been found that many of the older methods yielded erroneously high normal values. In a previous communication on methods for the determination of blood iodine (1), the authors reported normal values for 10 males and 10 females which ranged between 2.5 and 3.7 gamma per 100 cc., amounts which are lower and less variable than those reported by earlier investigators. They also noted in this paper that 4 groups of workers $(2,3,4,5)$ who had employed the recently revised acid ashing methods obtained similarly low values. Therefore, on the basis of the published criticisms $(1,2,6,7)$ of the alkaline ashing and the Leipert methods, and an investigation of the possible sources of error in the permanganate ashing method, the authors concluded that credence must be given to the low values for normal blood iodine.

In the present investigation the blood iodine levels have been determined in 55 patients with a number of different symptoms and signs of thyroid disorder. The results have been analyzed in an attempt to determine the relation of blood iodine to the symptoms and signs of hyperthyroidism.

\section{METHODS}

The basal metabolic rates were determined with the Benedict-Roth apparatus under the standard conditions which have been described by Benedict, Dubois and others. In many instances, the basal metabolic rates obtained on the morning after the patient's admission to the hospital were omitted because it was feared that the patient was apprehensive or excited. In such instances, the values represent the determinations 2 to 4 days after admission to the hospital, when the patient was more adjusted to the basal metabolic test. In a few instances, Lugol's solution had been given for 3 days before these second metabolism tests were determined.

1 This work was aided in part by grants from the Knight and Fluid Research Funds, Yale University, School of Medicine.

2 Alexander Brown Coxe Memorial Fellow, Departments of Physiology, Psychiatry and Mental Hygiene, Yale University, School of Medicine, 1940-41.
Venous blood was taken under post-absorptive conditions and the serum analyzed for cholesterol by methods previously described $(8,9)$. Blood iodine was determined by the permanganate acid ashing method, which yields average recoveries of 95 per cent (1). No patient had had Lugol's solution, iodized salt or any form of iodine therapy during the 3 weeks before measurement of the blood iodine. Furthermore, no patient had had any diagnostic test in which an iodine-containing contrast medium was used, except B5469 (Table III) who had had lipiodol 10 years previously.

\section{DATA}

The largest group (Table I) consists of 31 patients with definite hyperthyroidism. All the patients except the 3 at the end had thyroidectomies. The first 28 cases are listed in the numerical order of the hospital records. Tables II and III present data on patients with complications or nervous system disorders, in whom hyperthyroidism was considered or was doubtful. For comparison, the iodine has been determined in the blood of 6 patients (Table IV) with nodular enlargement of the gland but with no systemic signs of thyroid overactivity. The blood iodine has also been evaluated in 7 patients with signs and symptoms of myxedema.

Owing to the fact that clinical evaluation of the degree of thyroid overactivity is difficult and somewhat subjective, the diagnostic estimates were made by 2 or 3 physicians without knowledge of the blood iodine or serum lipoid values. Subsequently, the 48 patients were divided into 4 groups in accordance with the presence or absence of thyroid enlargement, exophthalmos, tremor, restlessness, cardiac enlargement, tachycardia, warm, flushed skin, increased perspiration and malnutrition. In addition to these clinical symptoms, the height of the basal metabolic rate was an important criterion. The patient's response to iodine or thyroidectomy was also used in evaluating the original diagnosis.

The blood iodines, serum cholesterols and symptoms of hyperthyroidism of the patients at the time of admission to the hospital are given in the tables. Cases that are marked with asterisks presented certain unusual clinical features which are mentioned in the protocols.

Improvement of the patients is indicated in the 3 columns at the right of the tables. Basal metabolic rates after Lugol's, but before thyroidectomy, and after operation are given. Clinical improvement after Lugol's therapy has been graded ++ in those patients whose pulse rates fell, who gained in weight and who became calm and quiet, + when the improvement was not as marked, and \pm when it was impossible to tell whether iodine 
TABLE I

Patients with symptoms of definite hyperthyroidism

\begin{tabular}{|c|c|c|c|c|c|c|c|c|c|c|c|c|}
\hline \multirow{3}{*}{$\begin{array}{l}\text { Case number, } \\
\text { sex and age }\end{array}$} & \multirow{3}{*}{$\begin{array}{l}\text { Blood } \\
\text { iodine }\end{array}$} & \multirow{3}{*}{$\begin{array}{c}\text { Serum } \\
\text { choles- } \\
\text { terol }\end{array}$} & \multirow{3}{*}{$\begin{array}{l}\text { Basal } \\
\text { meta- } \\
\text { bolic } \\
\text { rate }\end{array}$} & \multicolumn{4}{|c|}{ Symptoms of hyperthyroidism } & \multirow{3}{*}{$\begin{array}{l}\text { Duration } \\
\text { hyper- } \\
\text { thyroid } \\
\text { symptoms }\end{array}$} & \multirow{3}{*}{$\begin{array}{c}\text { Nutri- } \\
\text { tion }\end{array}$} & \multicolumn{3}{|c|}{ Improvement } \\
\hline & & & & \multirow{2}{*}{$\begin{array}{l}\text { Thyroid } \\
\text { enlargement }\end{array}$} & \multirow{2}{*}{ Tremor } & \multirow{2}{*}{ Exoph- } & \multirow{2}{*}{ Skin } & & & \multicolumn{2}{|c|}{$\begin{array}{c}\text { After Lugol's, } \\
\text { before } \\
\text { thyroidectomy }\end{array}$} & \multirow{2}{*}{\begin{tabular}{|c}
$\begin{array}{c}\text { After } \\
\text { thyroid- } \\
\text { ectomy }\end{array}$ \\
$\begin{array}{c}\text { Basal } \\
\text { meta- } \\
\text { bolic } \\
\text { rate }\end{array}$ \\
\end{tabular}} \\
\hline & & & & & & & & & & $\begin{array}{c}\text { Clinical } \\
\text { symp- } \\
\text { toms }\end{array}$ & $\begin{array}{l}\text { Basal } \\
\text { meta- } \\
\text { bolic } \\
\text { rate }\end{array}$ & \\
\hline $\begin{array}{r}4342 \\
F \quad 46 \\
\end{array}$ & $\mid \begin{array}{c}g a m m a \\
p e r \\
100 \\
7.5\end{array}$ & $\begin{array}{c}\text { mgm. } \\
\text { per } \\
100 \text { cc. }\end{array}$ & $\begin{array}{c}\text { per } \\
\text { cent } \\
+26\end{array}$ & $\begin{array}{l}++ \text { Nodular } \\
4 \text { years }\end{array}$ & 0 & 0 & 0 & $\begin{array}{l}\text { months } \\
216\end{array}$ & N. & + & $\begin{array}{c}\text { per } \\
\text { cent } \\
+12\end{array}$ & $\begin{array}{l}\text { per } \\
\text { cent } \\
+9\end{array}$ \\
\hline $\begin{array}{r}10184 \\
M \quad 41\end{array}$ & 7.7 & & +43 & ++ & ++ & 0 & ++ & 36 & $=$ & + & +28 & +5 \\
\hline$F^{10493} 32$ & 8.6 & 150 & +27 & +++ & + & ++ & 0 & $1 \frac{1}{2}$ & - & + & +1 & -16 \\
\hline$F^{71934} 50$ & 8.5 & 175 & +29 & ++ & + & + & + & 6 & - & ++ & +10 & +10 \\
\hline $\begin{array}{r}84098 \\
M \quad 32\end{array}$ & 17.9 & 84 & +41 & +++ & + & ++ & + & 24 & - & ++ & +7 & -9 \\
\hline $\begin{array}{l}\mathrm{A} 2590 \\
\mathrm{~F}\end{array}$ & 7.0 & 131 & +29 & + & + & 0 & ++ & 3 & $=$ & + & +17 & \\
\hline $\begin{array}{l}\text { A84439 } \\
\text { F } \quad 36\end{array}$ & 7.6 & 164 & +41 & ++ & + & 0 & + & 5 & $=$ & ++ & +5 & +1 \\
\hline $\begin{array}{l}\mathrm{A} 96720 \\
\mathrm{M} \quad 25\end{array}$ & 9.2 & 132 & +52 & ++ & + & 0 & +++ & 6 & - & + & +26 & -1 \\
\hline $\begin{array}{l}\mathrm{A} 97068 \\
\mathrm{~F} \quad 42\end{array}$ & 8.3 & 142 & +35 & ++ & ++ & + & ++ & 4 & - & + & +21 & -7 \\
\hline $\begin{array}{l}\mathrm{A} 99905 \\
\mathrm{~F}\end{array}$ & 12.1 & & +41 & + & 0 & 0 & ++ & 3 & - & + & +38 & -5 \\
\hline $\begin{array}{l}\text { B582 } \\
F\end{array}$ & 11.2 & 151 & +52 & ++ & ++ & 0 & ++ & 2 & N. & + & +20 & +6 \\
\hline $\begin{array}{l}\mathrm{B} 693 \\
\mathrm{~F}\end{array}$ & 21.9 & 99 & +71 & +++ Nodular & ++ & ++ & ++ & 24 & - & + & +55 & -8 \\
\hline $\mathrm{F}^{\mathrm{B} 832} 26$ & 13.6 & 103 & +36 & ++ & + & 0 & + & 4 & $=$ & ++ & +8 & +1 \\
\hline $\mathrm{B}^{\mathrm{B} 933} 30$ & 12.0 & 177 & +82 & ++ & + & + & + & 36 & N. & + & +11 & +16 \\
\hline $\begin{array}{l}\text { B3260 } \\
\text { F } \quad 26\end{array}$ & 14.2 & 170 & +66 & + & + & 0 & + & 4 & N. & ++ & +40 & +6 \\
\hline $\begin{array}{l}\text { B3296 } \\
\text { F } \quad 36\end{array}$ & 9.7 & 135 & +47 & ++ & + & 0 & ++ & 144 & N. & + & +27 & +6 \\
\hline $\begin{array}{l}\text { B3842 } \\
\text { F } \quad 24\end{array}$ & 9.6 & 91 & +57 & +++ Nodular & + & + & + & 2 & N. & ++ & +17 & -4 \\
\hline $\begin{array}{l}\text { B4123 } \\
\text { F } \quad 24\end{array}$ & 15.0 & 106 & +89 & +++ & ++ & ++ & ++ & 40 & - & + & +59 & +14 \\
\hline $\begin{array}{l}\mathrm{B} 4507 \\
\mathrm{~F}\end{array}$ & 7.4 & 183 & +38 & +++ & + & 0 & + & 4 & N. & + & +18 & +2 \\
\hline
\end{tabular}


TABLE I (Continued)

\begin{tabular}{|c|c|c|c|c|c|c|c|c|c|c|c|c|}
\hline \multirow{3}{*}{$\begin{array}{l}\text { Case number, } \\
\text { sex and age }\end{array}$} & \multirow{3}{*}{\begin{tabular}{|l} 
Blood \\
iodine
\end{tabular}} & \multirow{3}{*}{$\begin{array}{l}\text { Serum } \\
\text { choles- } \\
\text { terol }\end{array}$} & \multirow{3}{*}{$\begin{array}{l}\text { Basal } \\
\text { meta- } \\
\text { bolic } \\
\text { rate }\end{array}$} & \multicolumn{4}{|c|}{ Symptoms of hyperthyroidism } & \multirow{3}{*}{$\begin{array}{c}\text { Duration } \\
\text { hyper- } \\
\text { thyroid } \\
\text { symptoms }\end{array}$} & \multirow{3}{*}{$\begin{array}{c}\text { Nutri- } \\
\text { tion }\end{array}$} & \multicolumn{3}{|c|}{ Improvement } \\
\hline & & & & \multirow{2}{*}{$\begin{array}{c}\text { Thyroid } \\
\text { enlargement }\end{array}$} & \multirow{2}{*}{ Tremor } & \multirow[b]{2}{*}{$\begin{array}{l}\text { Exoph- } \\
\text { thalmos } \\
\end{array}$} & \multirow{2}{*}{ Skin } & & & \multicolumn{2}{|c|}{$\begin{array}{l}\text { After Lugol's, } \\
\text { before } \\
\text { thyroidectomy }\end{array}$} & \multirow{2}{*}{\begin{tabular}{|c}
$\begin{array}{c}\text { After } \\
\text { thyroid- } \\
\text { ectomy }\end{array}$ \\
$\begin{array}{c}\text { Basal } \\
\text { meta- } \\
\text { bolic } \\
\text { rate }\end{array}$ \\
\end{tabular}} \\
\hline & & & & & & & & & & $\begin{array}{l}\text { Clinical } \\
\text { symp- } \\
\text { toms }\end{array}$ & $\begin{array}{l}\text { Basal } \\
\text { meta- } \\
\text { bolic } \\
\text { rate }\end{array}$ & \\
\hline $\begin{array}{l}\text { B4719 } \\
F \quad 48\end{array}$ & $\begin{array}{l}\text { gamma } \\
\text { per } \\
100 \text { cc. } \\
14.9\end{array}$ & $\begin{array}{c}\text { mgm. } \\
\text { per } \\
100 \text { cc. } \\
112\end{array}$ & $\begin{array}{l}\text { per } \\
\text { cent } \\
+54\end{array}$ & ++ & ++ & + & + & $\begin{array}{c}\text { months } \\
6\end{array}$ & - & + & $\begin{array}{c}\text { per } \\
\text { cent } \\
+15\end{array}$ & $\begin{array}{l}\text { per } \\
\text { cent } \\
-4\end{array}$ \\
\hline $\begin{array}{l}\text { B5149 } \\
\text { F } \quad 43\end{array}$ & 8.2 & 179 & +39 & + & + & 0 & + & $\begin{array}{c}2 \\
16 \text { years } \\
\text { recurrent }\end{array}$ & - & + & +15 & -2 \\
\hline $\begin{array}{l}\text { B5252 } \\
\text { F } 26\end{array}$ & 9.6 & 162 & +37 & ++ & ++ & 0 & ++ & 7 & N. & + & +13 & +3 \\
\hline $\begin{array}{l}\text { B5309 } \\
\text { F } \quad 46\end{array}$ & 12.9 & 130 & +54 & ++ & ++ & 0 & ++ & 3 & $=$ & + & +25 & +1 \\
\hline $\begin{array}{l}\text { B6138 } \\
\text { F } \quad 41\end{array}$ & 9.5 & 146 & +55 & ++ & + & 0 & + & 2 & - & + & +36 & -1 \\
\hline $\begin{array}{l}\text { B6234 } \\
\text { M } 27\end{array}$ & 7.2 & 116 & +68 & ++ & ++ & + & +++ & 12 & $=$ & + & +21 & +1 \\
\hline $\begin{array}{l}\text { B7257 } \\
\text { F } 16\end{array}$ & 16.5 & 109 & +86 & +++ & ++ & 0 & ++ & 7 & - & + & +45 & +18 \\
\hline $\begin{array}{l}\text { B7329 } \\
\text { F } \quad 41\end{array}$ & 6.4 & 125 & +27 & + Nodular & + & 0 & + & 36 & ob. & + & +9 & -10 \\
\hline $\begin{array}{l}\text { B8749 } \\
\text { F } \quad 40\end{array}$ & 11.6 & & +68 & ++ & ++ & + & + & 12 & - & + & +44 & +11 \\
\hline $\mathrm{F}^{1} 58$ & 7.8 & 158 & +12 & $\stackrel{+}{15}$ years & + & 0 & 0 & 9 & $=$ & + & & \\
\hline $\begin{array}{r}99948 \\
33\end{array}$ & 7.2 & 183 & +24 & + Nodular & + & 0 & + & 12 & N. & + & +4 & \\
\hline $\begin{array}{l}\text { B4777* } \\
\text { F } 56\end{array}$ & 9.2 & 95 & +52 & $\begin{array}{l}+ \text { Nodular } \\
7 \text { years }\end{array}$ & + & 0 & ++ & 24 & $=$ & + & +26 & \\
\hline
\end{tabular}

therapy had been of benefit. A blank space indicates that there were no data because Lugol's therapy was not tried or because there was no operation. It was impossible to state whether the operated patients were permanently improved since all these patients have been studied within the last 15 months.

Enlargement of the thyroid has been graded as + when the gland was slightly palpable, ++ when large, and +++ when large with bruit. Sub indicates a substernal thyroid. Under tremor + indicates a perceptible fine tremor of the extended tongue or fingers of the hand, ++ an easily recognizable tremor. Any perceptible exophthalmos or lid lag has been listed as + . Where the signs of exophthalmos were marked, ++ has been used. Under skin have been included flushing, sweating, and satiny texture. Different degrees of flushing and sweating have been described as $t$ to $++t$. Nutrition has been rated as $\mathrm{N}$. when normal or average, - when approximately 10 per cent of weight has been lost, and = when emaciation was more severe. For people who remained distinctly well nourished, + has been used, and ob. indicates overweight of an extreme degree in which the distribution of fat was eccentric.

The chart presents diagrammatically the iodine values obtained by duplicate analyses of the blood of 26 normal subjects, of the 31 clear-cut hyperthyroid patients of $\mathrm{Ta}$ ble I and of the patients in Tables II and III. For comparison, values from 6 subjects with nodular goiter 
TABLE II

Patients with complications in whom hyperthyroidism was doubtful

\begin{tabular}{|c|c|c|c|c|c|c|c|c|c|c|c|c|}
\hline \multirow{3}{*}{$\begin{array}{c}\text { Case } \\
\text { number, } \\
\text { sex and age }\end{array}$} & \multirow{3}{*}{$\begin{array}{l}\text { Blood } \\
\text { iodine }\end{array}$} & \multirow{3}{*}{$\begin{array}{l}\text { Serum } \\
\text { choles- } \\
\text { terol }\end{array}$} & \multirow{3}{*}{$\begin{array}{l}\text { Basal } \\
\text { meta- } \\
\text { bolic } \\
\text { rate }\end{array}$} & \multicolumn{4}{|c|}{ Symptoms of hyperthyroidism } & \multirow{3}{*}{$\begin{array}{c}\text { Duration } \\
\text { of symp- } \\
\text { toms. }\end{array}$} & \multirow{3}{*}{$\underset{\text { Nion }}{\text { Nutri- }}$} & \multicolumn{3}{|c|}{ Improvement } \\
\hline & & & & \multirow{2}{*}{$\begin{array}{c}\text { Thyroid } \\
\text { enlargement }\end{array}$} & \multirow[b]{2}{*}{ Tremor } & \multirow{2}{*}{$\begin{array}{l}\text { Exoph- } \\
\text { thalmos }\end{array}$} & \multirow[b]{2}{*}{ Skin } & & & \multicolumn{2}{|c|}{$\begin{array}{l}\text { After Lugol's, } \\
\text { before } \\
\text { thyroidectomy }\end{array}$} & \multirow{2}{*}{$\begin{array}{c}\begin{array}{c}\text { After } \\
\text { thyroid- } \\
\text { ectomy }\end{array} \\
\begin{array}{c}\text { Basal } \\
\text { meta- } \\
\text { bolic } \\
\text { rate }\end{array} \\
\end{array}$} \\
\hline & & & & & & & & & & $\begin{array}{c}\text { Clinical } \\
\text { symp- } \\
\text { toms }\end{array}$ & $\begin{array}{l}\text { Basal } \\
\text { meta- } \\
\text { bolic } \\
\text { rate }\end{array}$ & \\
\hline $\mathrm{F}^{84736^{*}} 52$ & $\begin{array}{c}\text { gamma } \\
\text { per } \\
100 \text { cc. } \\
6.4\end{array}$ & $\begin{array}{c}\text { mgm. } \\
\text { per } \\
100 \text { cc. } \\
113\end{array}$ & $\begin{array}{l}\text { per } \\
\text { cent } \\
+92\end{array}$ & $\begin{array}{l}+ \text { Nodular } \\
10 \text { years }\end{array}$ & 0 & 0 & + & $\begin{array}{c}\text { months } \\
120\end{array}$ & $=$ & \pm & $\begin{array}{l}\text { per } \\
\text { cent }\end{array}$ & $\begin{array}{l}\text { per } \\
\text { cent }\end{array}$ \\
\hline 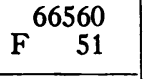 & 5.9 & 243 & +16 & + & 0 & 0 & + & 4 & ++ & & & \\
\hline $\begin{array}{l}\mathrm{B} 3513 \\
\mathrm{~F}\end{array}$ & 7.4 & 105 & +22 & + & ++ & 0 & +++ & 10 & $=$ & \pm & +20 & \\
\hline $\begin{array}{l}\text { B10541 } \\
\text { F }\end{array}$ & 6.3 & 149 & +26 & + Sub. & + & 0 & ++ & 24 & N. & \pm & +20 & \\
\hline $\mathrm{F}^{45153^{*}} 5$ & 8.9 & 233 & +32 & + & 0 & 0 & + & 7 & N. & + & +19 & \\
\hline $\mathrm{F}^{91064^{*}}$ & 7.6 & 218 & +23 & ? Sub. & + & 0 & ++ & 36 & N. & \pm & +6 & \\
\hline $\begin{array}{l}\text { B } 4976^{*} \\
\end{array}$ & 7.6 & 154 & +11 & 0 & 0 & 0 & + & 12 & $=$ & & & \\
\hline
\end{tabular}

and without signs of thyroid overactivity (Table IV), and from 7 patients with myxedema have been included. The narrow normal range is clearly indicated.

\section{RESULTS}

All the patients in Table I had definite symptoms of hyperthyroidism. With the exception of 4342, 10493, 71934, A2590, B7329, 1, and 99948 the basal metabolic rates before Lugol's were between plus 35 and plus 89 per cent. After Lugol's all the patients had clinical improvement and the basal metabolic rates fell in all except Case 1. The thyroid was large in all but 7 cases, A2590, A99905, B3260, B5149, B7329, 99948 and B4777, in which it was distinctly palpable. In 7 cases there was a definite bruit as has been noted by +++ in the thyroid enlargement column. Clinically, hyperplasia of the thyroid was diagnosed in 25 patients, and nodular goiter with thyroid overactivity in 6 . Tremor was a characteristic symptom of all the patients except A99905 and 4342. Satiny texture of the skin, typical of hyperthyroid patients, was noted in all
31 subjects with the exception of 1,4342 , and 10493. In 21 patients the nutrition was poor and there had been a loss of at least 10 per cent of the individual's usual body weight.

The 7 patients, with the exception of 84736 in Table II, had symptoms of hyperthyroidism which were not as outstanding as those of the patients in Table I. This can be seen easily in the table under " Symptoms of hyperthyroidism." Only 2 had basal metabolic rates above plus 30 per cent. None of the patients had a thyroidectomy.

The patients in Table III did not have definite symptoms of hyperthyroidism. Their basal metabolic rates varied between minus 10 and plus 25 per cent. Vasomotor and emotional instability was pronounced and the possibility of hyperthyroidism was considered.

The blood iodines of all the 31 patients in Table I were above the normal range. This is shown graphically in Figure 1. There was no overlapping with the normal values. The blood iodines ranged from 6.4 to 21.9 with an average of 10.6 gamma per $100 \mathrm{cc}$., while 2.4 to 4.2 with 
TABLE III

Patients in whom hyperthyroidism was considered because of nervous symptoms or vasomotor instability

\begin{tabular}{|c|c|c|c|c|c|c|c|c|c|c|c|c|}
\hline \multirow{4}{*}{$\begin{array}{c}\text { Case } \\
\text { number, } \\
\text { sex and } \\
\text { age }\end{array}$} & \multirow{4}{*}{ 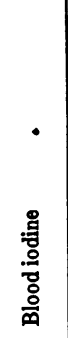 } & \multirow{4}{*}{ 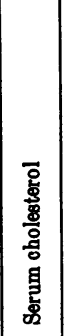 } & \multirow{4}{*}{ 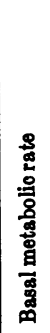 } & \multirow{2}{*}{\multicolumn{4}{|c|}{$\begin{array}{c}\text { Symptoms of } \\
\text { hyper- } \\
\text { thyroidism }\end{array}$}} & \multirow{4}{*}{ 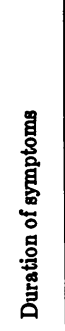 } & \multirow[b]{4}{*}{ 点 } & \multicolumn{3}{|c|}{ Improvement } \\
\hline & & & & & & & & & & \multirow{2}{*}{\multicolumn{2}{|c|}{$\begin{array}{l}\text { After } \\
\text { Lugol's, } \\
\text { before } \\
\text { thyroid- } \\
\text { ectomy }\end{array}$}} & \multirow{3}{*}{ 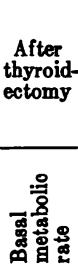 } \\
\hline & & & & \multirow{2}{*}{ 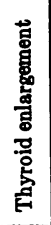 } & \multirow[b]{2}{*}{ 密 } & \multirow[b]{2}{*}{ 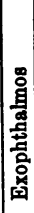 } & \multirow[b]{2}{*}{ 总 } & & & & & \\
\hline & & & & & & & & & & 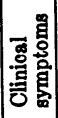 & 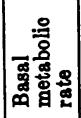 & \\
\hline $\mathrm{M}^{53949^{*}}$ & $\begin{array}{c}\text { oamma } \\
\text { per } \\
100 \\
c c . \\
4.8\end{array}$ & $\begin{array}{c}\text { mom. } \\
\text { per } \\
100 \\
\text { cc. } \\
174\end{array}$ & $\begin{array}{c}\text { per } \\
\text { cent } \\
+25\end{array}$ & ++ & + & + & + & months & $\mathbf{N}$ & \pm & $\begin{array}{c}\text { per } \\
\text { cent } \\
+16\end{array}$ & $\begin{array}{l}\text { per } \\
\text { cent } \\
+3\end{array}$ \\
\hline $\begin{array}{l}\text { A29870* } \\
\text { F } 41\end{array}$ & 3.6 & 230 & +5 & + & + & 0 & 0 & 84 & $\mathbf{N}$ & & & \\
\hline $\begin{array}{l}\mathrm{B} 5465^{*} \\
\mathrm{~F}\end{array}$ & 4.9 & 192 & -3 & + & 0 & 0 & 0 & 18 & $\mathbf{N}$ & \pm & -8 & \\
\hline $\begin{array}{l}\mathrm{B} 5469^{*} \\
\mathrm{~F}\end{array}$ & 4.2 & 241 & -10 & 0 & 0 & 0 & 0 & 180 & $\overline{=}$ & & & \\
\hline
\end{tabular}

an average of 3.1 gamma per $100 \mathrm{cc}$. represents the range of our present series of 26 normal subjects.

The height of the blood iodine was not related to the duration of symptoms. For example, 2 of the highest values, 17.9 (84098) and 15 gamma per cent (B4123) occurred in patients who had had symptoms for 24 and 40 months. The average of the blood iodines of the 18 patients with symptoms lasting less than 12 months was 10.5 , and of the 13 patients with symptoms for 12 months or longer was 10.9 gamma per cent.

The 7 patients in Table II, in whom hyperthyroidism was doubtful because of complications, also had elevated blood iodines ranging from 5.9 to 8.9 gamma per cent. Case 84736 has been diagnosed as a hyperthyroid for 10 years. She has had pernicious anemia and has refused thyroidectomy. Cases 66560, B3513 and B10541, with blood iodines of only $5.9,7.4$, and 6.3 gamma per cent, had symptoms suggestive of early hyperthyroidism. The significance of the elevation in blood iodine of B4976 and 91064 is not clear. These studies on patients in Table II show that the blood iodine may be elevated without the accompaniment of definite hyperthyroidism.

The patients in Table III did not have definite symptoms of hyperthyroidism. Case 53949, with a blood iodine of 4.8 gamma per cent-not ap-
TABLE IV

Patients with nodular goiter but without definite signs of thyroid activity

\begin{tabular}{|c|c|c|c|c|c|c|c|c|c|c|c|}
\hline \multirow{3}{*}{$\begin{array}{c}\text { Case } \\
\text { number, } \\
\text { sex } \\
\text { and } \\
\text { age }\end{array}$} & \multirow[b]{3}{*}{ 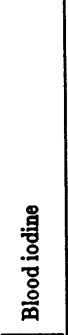 } & \multirow{3}{*}{ 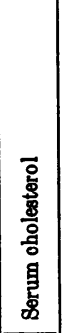 } & \multirow{3}{*}{ 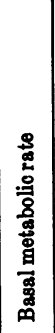 } & \multicolumn{4}{|c|}{$\begin{array}{l}\text { Symptoms of } \\
\text { hyperthyroidism }\end{array}$} & \multicolumn{4}{|c|}{ Improvement } \\
\hline & & & & \multirow{2}{*}{ 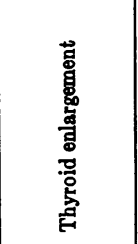 } & \multirow[b]{2}{*}{ 惫 } & \multirow[b]{2}{*}{ 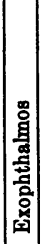 } & \multirow{2}{*}{\multicolumn{2}{|c|}{ 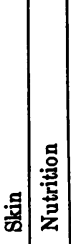 }} & \multicolumn{2}{|c|}{$\begin{array}{l}\text { After } \\
\text { Lugol's, } \\
\text { before } \\
\text { thyroid- } \\
\text { ectomy }\end{array}$} & \multirow{2}{*}{ 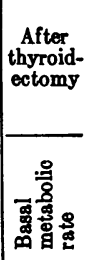 } \\
\hline & & & & & & & & & 兽茴 & 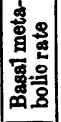 & \\
\hline $\mathrm{F}^{2} 26$ & $\begin{array}{c}\text { gamma } \\
\text { per } \\
100 \\
c c . \\
1.8\end{array}$ & $\begin{array}{c}\text { mgm. } \\
\text { per } \\
100 \\
c c .\end{array}$ & $\begin{array}{l}\text { per } \\
\text { cent } \\
-2\end{array}$ & ++ Nodular & 0 & 0 & 0 & N. & \pm & $\begin{array}{l}\text { per } \\
\text { cent }\end{array}$ & $\begin{array}{l}\text { per } \\
\text { cent }\end{array}$ \\
\hline$M^{4404} 21$ & 2.9 & & +15 & $\begin{array}{l}\text { Nodular } \\
16 \text { years }\end{array}$ & 0 & 0 & 0 & N. & & & \\
\hline $\begin{array}{r}\text { A60174 } \\
\mathrm{F} \quad 43\end{array}$ & 3.6 & & +16 & $\begin{array}{l}\text { Calcified } \\
\text { Nodule }\end{array}$ & 0 & 0 & + & - & & & \\
\hline $\begin{array}{l}\mathrm{B} 8554 \\
\mathrm{~F} \quad 56\end{array}$ & 3.9 & 217 & +31 & ++ Nodular & + & 0 & + & ob. & \pm & +28 & \\
\hline $\begin{array}{l}\text { P2439 } \\
\text { F } \quad 37\end{array}$ & 3.0 & 205 & -7 & $\begin{array}{l}++ \text { Nodular } \\
12 \text { years }\end{array}$ & + & 0 & 0 & + & & & \\
\hline $\begin{array}{l}\text { P2496 } \\
\text { F } 76\end{array}$ & 4.9 & 305 & +28 & $\begin{array}{l}+ \text { Nodular } \\
62 \text { years }\end{array}$ & ++ & 0 & 0 & N. & \pm & & \\
\hline
\end{tabular}

preciably above the normal range-had a thyroidectomy because slight overactivity of the thyroid might be aggravating cardiac decompensation. $\mathrm{He}$ did not improve after thyroidectomy.

The 6 patients in Table IV, who had nodular goiters without symptoms of thyroid overactivity, had blood iodines within or not significantly dif-

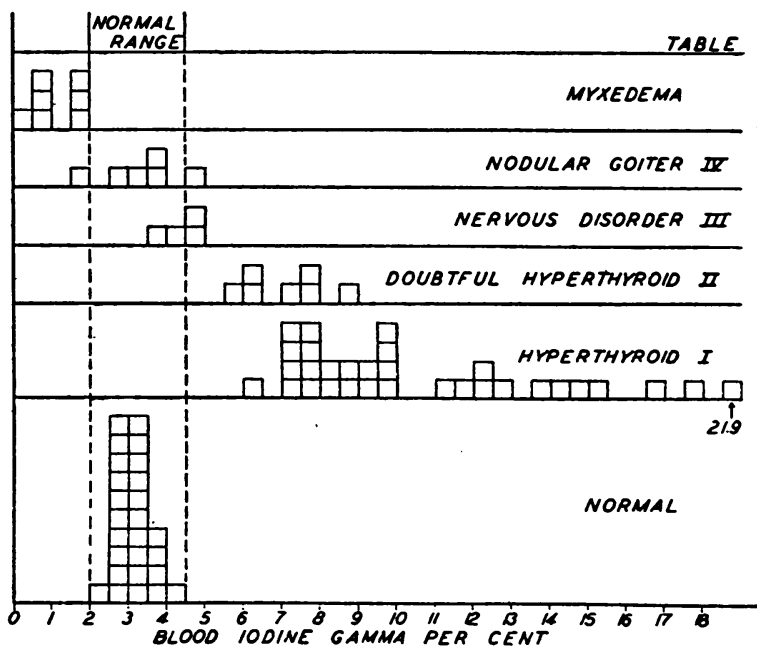

Frg. 1. A Comparison of Blood Iodine Values in Normal Subjects, and in Patients with Hyperthyroidism, Myxedema, and Nervous Disorders 
ferent from the normal range. This is shown clearly in Figure 1.

In Figure 1 it can be seen that the blood iodine of each of the 7 myxedema patients was below the normal range. The values varied from 0.3 to 1.7 gamma per cent. All these patients had classical symptoms of myxedema. Two developed symptoms some years after thyroidectomy when thyroid medication was stopped temporarily. These patients will be described more fully in an article to be published.

Only 16 of the 27 definite hyperthyroid patients in Table I, who had serum cholesterol determinations, had cholesterols below the minimum of the normal range- 150 milligrams per cent. For this reason, blood iodine is a more useful measure of thyroid overactivity than serum cholesterol.

\section{DISCUSSION}

The finding that the blood iodines of all 31 definite hyperthyroid patients were 1.5 to 5 times the highest normal value is at variance with previous observations. This is due partially to the fact that the iodines of our 26 normal subjects all fell within the narrow range of 2.4 to 4.2 gamma per cent. This range is wider than that previously published (1) owing to the addition of 6 normal subjects to our series. Five of the euthyroid individuals included in Figure 1 have been studied repeatedly at various times of the year. Only one determination on each of these individuals is included in the figure, but at no time of the year did their blood iodines exceed the normal range given above. It seems, therefore, that this normal range will not be increased by fluctuations which might be related to the season of the year. Our normal values agree closely with those of Baumann and Metzger (2) who found blood iodines ranging from 2.3 to 4.4 in 10 normal male and 10 normal female subjects. The lack of overlapping with the normal figures in the present study makes it improbable that a normal blood iodine will be found in a larger series of patients with hyperthyroidism. In view of the reports of Perkin and his associates $(10,11,12)$ that normal blood iodine values are frequently found in patients with long-standing symptoms of hyperthyroidism, the duration of symptoms was carefully evaluated. It has been noted in the results that the average blood iodine of patients with symptoms which had persisted from 12 to 216 months was practically the same as the average blood iodine of patients with symptoms of less than a year's duration.

Salter in his recent comprehensive monograph (13) and Davis, Curtis and Cole (14) have discussed the older published values showing large variations in blood iodine of hyperthyroid patients. Salter has described differences in values attributable to the region where the subject lives. Perkin and Lahey (12), Curtis and Puppel (15), as well as Salter, have pointed out that refinements in chemical techniques have resulted in lower blood iodine values of both normal and hyperthyroid subjects. Since the earlier values have been adequately discussed, our data need to be compared only with those published in 1940 by 3 different groups of workers.

The average blood iodines of normal and of hyperthyroid subjects reported by Klassen, Bierbaum and Curtis (16) agree with ours, but their normal range extends higher and their hyperthyroid range lower than ours. Thus, their normal values vary from 3.1 to 5.6 with an average of 4.0 gamma per cent, while their hyperthyroid values vary from 5.5 to 15.7 with an average of 10.0 gamma per cent. The analyses of Klassen, Bierbaum and Curtis were made on one aliquot of blood. A single analysis may at times be slightly high or low, and this may explain the slight overlapping of normal and hyperthyroid values which they have found. Our figures are the average of duplicate determinations which usually did not differ by more than 0.3 gamma per cent. Occasionally, when our duplicates failed to check within 0.5 gamma per cent, a triplicate analysis was made.

The results of Klassen, Bierbaum and Curtis agree more satisfactorily with the data presented in this paper than the findings of Turner, DeLamater and Province, and of Perkin. Turner, DeLamater and Province (17) found a wider range of 3.5 to 10.4 gamma per cent in 20 normal males and 20 normal females and a higher normal average of 6.3 gamma per $100 \mathrm{cc}$. These investigators made duplicate analyses, using the method of Trevorrow and Fashena. Their normal values are in close agreement with Fashena's (18) normal range of 3.0 to 12.0 and average of 6.6 gamma per cent in 79 children 2 days to 13 years in age. For some reason Fashena's method gives higher 
normal values than have been found by Curtis and his associates $(4,15,16)$, by Grauer and Saier (3) and by Baumann and Metzger (2). The results of the latter workers were cited above. Turner, DeLamater and Province found a marked variation in the blood iodine of normal subjects and a wide range for their 20 hyperthyroid patients of 6.7 to 38.5 gamma per cent. The blood iodines of 6 of the 20 thyroid patients fell within the normal range. This overlapping is not surprising considering the wide fluctuations between the minimum and maximum normal and hyperthyroid values.

Perkin and Lahey (12) have found an even greater overlapping of normal and hyperthyroid values. They have found persons with no clinical evidence of thyrotoxicosis whose iodines ranged between 2 and 15 gamma per cent, although they have accepted 10 gamma per hundred $\mathrm{cc}$. as the upper limit of normal. About 34 per cent of their hyperthyroid patients had blood iodines of less than 10 gamma per cent. Their method of analysis depends on alkaline oxidation of the blood with alcoholic extraction of iodine compounds from the charred mass. This method has been criticized for the difficulties in technique and for erroneously high values $(2,15)$. Some of the enormous overlapping of normal and hyperthyroid values can therefore be attributed to technical difficulties in the analysis. In spite of wide variations in data, it can be concluded from all published figures that an elevation of blood iodine above the normal range is usual in hyperthyroid patients.

A high blood iodine, on the other hand, does not always connote definite hyperthyroidism. This was emphasized with respect to the patients in Table II. As has been stated, these patients had not had iodine solutions as contrast media for $\mathrm{x}$-ray diagnosis. This is important because diodrast may not be completely eliminated for days, iso-iodeikon (Graham-Cole test) for months and lipiodol for years. Of the 3 patients, 45153, 91064 and B4976, who had blood iodines of 8.9, 7.6, and 7.6 gamma per cent, the first 2 had cardiac enlargement and arteriosclerosis. Case 45153 also had diabetes which required insulin. All 3 had vasomotor or emotional instability. Their symptoms seemed to be more closely related to nervous system disorders than thyroid overactivity. $\mathrm{Pa}$ tients like these present a problem in clinical diag- nosis and it was hoped that the blood iodine would be a useful criterion to help distinguish them. However, all the patients in Table III had similar symptoms with blood iodines which were normal or only insignificantly elevated. Conclusions cannot be formulated until further studies of these and similar patients are completed. No attempt is made here to review the literature on this subject since Salter (13) has discussed at length the action of the thyroid hormone on the nervous system and the action of the nervous system on the thyroid.

The results on the 7 myxedematous patients were as clear-cut as those on the patients with hyperthyroidism. The highest blood iodine of 1.7 gamma per cent was well below the minimum normal value of 2.4 gamma per cent.

That the levels of blood iodine and serum cholesterol in thyroiditis are similar to those observed in definite hyperthyroidism was observed by Turner and his associates (17) and also noted by us in one female patient. Her blood iodine was 8.5 gamma per cent. Her basal metabolic rate was minus 5 per cent, and her serum cholesterol was 126 milligrams per cent, but she had no exophthalmos, motor restlessness or appearance of the skin typical of hyperthyroidism. Turner, DeLamater and Province reported elevated blood iodines of 11.2 and 11.3 gamma per cent in 2 cases of thyroiditis. The serum cholesterols were 124 and 141 milligrams per cent. These values approach the low levels in clear-cut hyperthyroidism (19).

\section{CONCLUSIONS}

The level of blood iodine has been found to be closely related to thyroid activity.

In 31 patients with hyperthyroidism the blood iodine ranged between 6.4 and 21.9 gamma per cent.

In 7 patients with myxedema it varied from 0.3 to 1.7 gamma per cent.

There was no overlapping with the normal range of 2.4 to 4.2 gamma per cent in 26 euthyroid subjects.

Six patients with nodular goiters but without symptoms of thyroid overactivity had blood iodines which did not differ significantly from normal.

It has been concluded that elevated blood iodine values are invariably found in hyperthyroid patients. However, certain patients without mani- 
fest hyperthyroidism may also have an elevated blood iodine. Further study of such patients is indicated.

It would have been impossible to collect this material if it had not been for the clinical services of Dr. Paul Lavietes, Dr. Alexander Winkler, and Dr. Kalmen A. Klinghoffer under whose care were many of the patients.

\section{PROTOCOLS}

B4777, female, aged 56. This patient had chronic myelogenous leukemia with a white count between 750 and 3000. The basal metabolic rate was plus 52 per cent, serum cholesterol 95 milligrams per cent, and blood iodine 9.2 gamma per cent. The response in basal metabolic rate to Lugol's confirmed the diagnosis of hyperthyroidism, but no operation was performed because of complications.

84736, female, aged 52. This patient had developed severe pernicious anemia 11 years previously. She also had slight exophthalmos, tremor, a nodule in the thyroid and a basal metabolic rate of plus 50 per cent at that time. She responded quite well to treatment with liver extract and iodine. After 2 years iodine was omitted and the patient did fairly well for 3 years. Then symptoms of hyperthyroidism returned and the basal metabolic rate was plus 31 per cent. Lugol's administration was followed by a remission. Iodine was stopped in June 1939 and she remained asymptomatic until June 1940 when palpitation, tremor and loss of weight returned. Operation was again advised and refused, as it had been many times before. In addition to hyperthyroid symptoms, the liver and spleen had become markedly enlarged. Iodine treatment was given from June to August 15, 1940, and then omitted. In October, the basal metabolic rate was plus 92 per cent, serum cholesterol 113 milligrams per cent, and blood iodine 6.4 gamma per cent. Subsequent return to iodine therapy was followed by modest improvement in 2 to 3 months. For the past 10 years the patient has required regular doses of liver or reticulogen to prevent return of anemia.

45153, female, aged 53. Hypertension had developed following toxemia of pregnancy 27 years previously. Diabetes mellitus and arteriosclerotic cardiovascular disease had been noted 10 years ago. The patient took insulin and digitalis so irregularly that she had repeated attacks of cardiac decompensation from which she recovered when adequate therapy with digitalis, insulin and diet was restored. Emotional instability, multiple complaints, unsteadiness of hands, flushing of skin, sweating, weight loss and diarrhea had become increasingly prominent during the last 2 years. On January 15, 1940, the basal metabolic rate was plus 32 , serum cholesterol 233 milligrams per cent, and blood iodine 8.9 gamma per cent. Lugol's therapy was followed by considerable improvement in all symptoms in 2 months.

91064, female, aged 66 . For the last 10 years recurrent and increasingly severe attacks of decompensation had been associated with arteriosclerotic cardiovascular disease. On the last hospital admission the patient had congestive heart failure with auricular fibrillation and anasarca. At this time she also had nervousness, tremor of hands and profuse sweating, although the thyroid was not enlarged. The basal metabolic rate was plus 23 per cent, serum cholesterol 218 milligrams per cent and blood iodine 7.6 gamma per cent. She died in congestive failure 5 weeks later.

B4976, female, aged 35. This patient had had multiple complaints of anxiety, palpitation, anorexia, vomiting and loss of 60 pounds during the previous year. After KI therapy from January 17 to 31,1940 , she was reported to have improved. In May, 1940, the patient was well nourished, had moist skin and extensive leukoderma. She looked exhausted and depressed and her movements were slow, but she was also tense and irritable. On May 9, 1940 , the basal metabolic rate was plus 11 , serum cholesterol 154 milligrams per cent and blood iodine 7.6 gamma per cent, but other signs of hyperthyroidism were lacking. While anxiety and depression were the outstanding features, overactivity of the thyroid was not entirely ruled out. Iodine was not given and she was referred to psychiatrists for treatment.

53949, male, aged 38. Following osteomyelitis of the jaw 3 years previously, this patient had successively developed hypertension, albuminuria, restlessness, irritability and a basal metabolic rate of plus 25. On admission, June 19, 1940, he was excitable, talkative, well nourished, and had prominent eyes, enlarged thyroid, hypertensive arteriosclerosis and an enlarged heart with slight decompensation. The serum cholesterol was $\mathbf{1 7 4}$ milligrams per cent and blood iodine 4.8 gamma per cent. Lugol's administration produced slight improvement. Subtotal thyroidectomy was followed by little change in symptoms and 2 months later the patient was unimproved although the basal metabolic rate was plus 3 per cent.

A29870, female, aged 41. This restless, apprehensive patient had had repeated illnesses characterized by weakness, insomnia, "palpitation," emotional upset, weight loss and varying physical complaints for 15 to 20 years. During these illnesses the basal metabolic rate had varied between plus 25 and plus 5 per cent. Response to iodine administration was uncertain because remissions also occurred without iodine. The last attack began in April, 1940, with pain in the epigastrium followed by loss of appetite and weight. On admission, September 16, 1940, the multiple complaints and emotional lability were striking. There was sweating and inconstant tremor of hands. The basal metabolic rate was plus 5 per cent, blood iodine 3.6 gamma per cent and serum cholesterol 230 milligrams per cent. Rest in bed without iodine resulted in marked improvement in symptoms. Emotional instability and spells of depression remained, although the tremor had disappeared. As all symptoms were referable to nervous system disorders, and other signs of thyroid disorder were lacking, the patient was referred to psychiatry for treatment.

B5465, female, aged 43. Fifteen months previously nervousness, which had been noticed for years, had become more marked and, subsequently, palpitation, prom- 
inence of eyes, tremulousness and dyspnoea appeared. In addition, the menses became irregular and she lost weight. On admission the patient was tense and apprehensive and had a slight tremor of the hands. Her blood pressure was 140/98 and the pulse 140 . By the next day most of her symptoms had subsided, and little but the vasomotor instability could be elicited. The thyroid was palpable, the right lobe being larger than the left. On May 28, 1940, the basal metabolic rate was minus 3 per cent, serum cholesterol 192 milligrams per cent and blood iodine 4.9 gamma per cent. Two weeks of treatment with Lugol's therapy and bed rest did not relieve vasomotor lability or complaints of nervousness. The diagnosis was former hyperthyroidism in remission and beginning menopause.

B5469, female, aged 27. Severe headaches, fainting spells, narcolepsy and intermittent bouts of fever had developed after the patient had broken her nose 15 years previously. In addition, she had had sinusitis and mastoiditis which had been relieved by mastoidectomy 14 years ago. Later, occasional attacks of hives and edema had occurred. All these symptoms continued, being interrupted by partial remissions lasting a few months to 3 years. In the previous 2 to 3 years, bouts of fever, nausea, vomiting, and loss of 55 pounds had occurred. The patient was poorly nourished and dehydrated on admission, but fever of $101^{\circ}$ subsided in 2 days. On June 4,1940 , the basal metabolic rate was minus 10 per cent, serum cholesterol 241 milligrams per cent and blood iodine 4.2 gamma per cent. Headaches and narcolepsy continued. It was concluded that the symptoms were probably due to a hypothalamic lesion of unknown etiology.

\section{BIBLIOGRAPHY}

1. Riggs, D. S., and Man, E. B., A permanganate acid ashing micromethod for iodine determinations. I. Values in blood of normal subjects. J. Biol. Chem., 1940, 134, 193.

2. Baumann, E. J., and Metzger, N., On the amount of iodine in blood. J. Biol. Chem., 1937, 121, 231.

3. Grauer, R. C., and Saier, E., A comparison of the distilling and dry ashing methods for the determination of blood iodine. Endocrinology, 1939, 24, 553.

4. Matthews, N. L., Curtis, G. M., and Brode, W. R., Determination of iodine in biological materials. Refinements of the chromium trioxide oxidation method. Ind. and Eng. Chem., Anal. Ed., 1938, 10,612 .

5. Stevens, C. D., Determination of iodine in biological materials. J. Lab. and Clin. Med., 1937, 22, 1074.

6. Trevorrow, V., and Fashena, G. J., The determination of iodine in biological material. J. Biol. Chem., 1935, 110, 29.

7. Fashena, G. J., and Trevorrow, V., A note on the determination of iodine in biological material. J. Biol. Chem., 1936, 114, 351.

8. Man, E. B., and Peters, J. P., Gravimetric determination of serum cholesterol adapted to the Man and Gildea fatty acid method with a note on the estimation of lipoid phosphorus. J. Biol. Chem., 1933, 101,685 .

9. Bogdanovitch, S. B., and Man, E. B., The effects of castration, theelin, testosterone and antuitrin-S on the lipoids of blood, liver and muscle of guinea pigs. Am. J. Physiol., 1938, 122, 73.

10. Perkin, H. J., and Lahey, F. H., Exophthalmic goiter. Relation between the blood iodine level and the duration of symptoms in three hundred and five cases. Arch. Int. Med., 1938, 61, 875.

11. Perkin, H. J., and Cattell, R. B., Blood iodine levels related to the recurrence of hyperthyroidism. Surg., Gynec. and Obst., 1939, 68, 744.

12. Perkin, H. J., and Lahey, F. H., The level of iodine in the blood. Arch. Int. Med., 1940, 65, 882.

13. Salter, W. T., The endocrine function of iodine. Harvard University Press, Cambridge, Mass., 1940.

14. Davis, C. B., Curtis, G. M., and Cole, V. V., Blood iodine studies. II. The normal iodine content of human blood. J. Lab. and Clin. Med., 1934, 19, 818.

15. Curtis, G. M., and Puppel, I. D., The iodine metabolism in exophthalmic goiter. Ann. Surg., 1938, 108, 574.

16. Klassen, K. P., Bierbaum, R. L., and Curtis, G. M., The comparative iodine content of whole blood and serum. J. Lab. and Clin. Med., 1940, 26, 365.

17. Turner, K. B., DeLamater, A., and Province, W. D., Observations on the blood iodine. I. The blood iodine in health, in thyroid and cardiorenal disease, and in leukemia. J. Clin. Invest., 1940, 19, 515.

18. Fashena, G. J., A study of the blood iodine in childhood. J. Clin. Invest., 1938, 17, 179.

19. Man, E. B., Gildea, E. F., and Peters, J. P., Serum lipoids and proteins in hyperthyroidism. J. Clin. Invest., 1940, 19, 43. 